\title{
Use of Moringa oleífera Lamarck leaf extract as sugarcane juice clarifier: effects on clarifed juice and sugar
}

Gustavo Henrique Gravatim COSTA ${ }^{1 *}$, Igor dos Santos MASSON, Lidyane Aline de FREITA, Juliana Pelegrini ROVIERO, Márcia Justino Rossini MUTTON

\begin{abstract}
The objective of this study was to evaluate the effect of Moringa oleifera Lam. leaf extract on the sedimentation of impurities in the treatment of sugarcane juice and the effects on sugar quality and on the clarified juice. The experimental design used was a $4 \times 2$ factorial arrangement with four replications. The main treatments performed included the extracted original sugarcane juice, the synthetic polyelectrolyte (Flomex 9076), the leaf extract, and a control. The secondary treatments consisted of the sugarcane varieties RB92579 and RB867515. The clarification process used was simple defecation, in which the flocculating agents and the juice, limed and heated, were poured simultaneously into a decanter. The microbiological and chemico-technological characteristics of the extracted and clarified juices were evaluated. The clarified juice was concentrated up to $60^{\circ}$ Brix (syrup) and subjected to boiling in a pilot pan using seeds to perform the graining. The sugar was recovered by centrifugation and analyzed for microbiological and chemico-technological characteristics. It was concluded that the use of the Moringa oleifera Lam. leaves extract resulted in a better quality of clarified juice and sugar.
\end{abstract}

Keywords: simple defecation; polyelectrolyte; biomolecule; sedimentation; sucroenergetic sector.

\section{Introduction}

Brazil is the world leader in sugar production; it has produced around 30-40 million tons per year over the past five years (Companhia Nacional de Abastecimento, 2013). The sugar market has great growth potential given the population growth and economic development of emerging economies such as China (Jank, 2011).

Therefore, studies on new technologies that contribute to increase productivity while reducing production costs in the industrial and agricultural sectors and enable product quality improvement are of fundamental importance. Under this likely scenario, simple procedures, such as the treatment of sugarcane juice stand out, which aims to remove impurities that negatively affect various stages of the production of sugar such as evaporation and crystallization (Rein, 2012).

Today, this treatment is due to the chemical reaction between the phosphate present in the juice and the calcium added (calcium hydroxide), which forms an insoluble flake that precipitates as calcium phosphate. During sedimentation, this molecule carries insoluble (earth) and soluble (chlorophyll and xanthophylls, among others) impurities. When solubilized in the sugarcane juice, these impurities can increase the ash content and color of sugar crystals, in addition to increasing the viscosity of the juice decreasing the sugar recovery in the industry (Albuquerque, 2011).

In order to accelerate the sedimentation of these particles, synthetic polyacrylamide-based polyelectrolytes are added, which are usually polar, anionic, long chain molecules that react with the calcium phosphate flakes formed increasing the size and weight of the flakes and hence the settling rate (Doherty, 2011).

However, due to the carcinogenicity of polyacrylamide, some countries such as the United States restrict the use of this product to the maximum of $5 \mathrm{mg} / \mathrm{kg}$ of juice (Foods and Drugs Administration of United States of America, 2014). This restriction has intensified the search for molecules derived from natural sources and that have properties that facilitate juice clarification and exhibit no toxicity, which may also increase the aggregate value of the product. Among the natural sources are plants, which could be grown within the agro-industrial area leading to further reduction in the final production costs.

Among the products studied, Moringa oleifera Lam. leaf and seed extract stand out since they are widely used for the treatment of water to precipitate soluble and insoluble impurities (Ndabigengesere \& Narasiah, 1998) and reduce the microbial load (Pritchard et al., 2010).

Seed extract has also been used to remove surfactants such as sodium lauryl sulfate from aqueous solutions (BeltránHeredia \& Sánchez-Martin, 2009). Other studies have also demonstrated the efficiency of this product in removing color and turbidity galvanoplasty's effluents (Vaz et al., 2010).

Accordingly, the current study was conducted to evaluate the efficiency of the Moringa oleifera Lam. leaf extract to assist impurity sedimentation in the treatment of sugarcane for the production of VHP sugar.

${ }^{1}$ Departamento de Tecnologia, Faculdade de Ciências Agrárias e Veterinárias - FCAV, Universidade Estadual Paulista "Júlio de Mesquita Filho" - UNESP, Jaboticabal, SP, Brasil,e-mail:ghg_costa@hotmail.com

${ }^{*}$ Corresponding author 


\section{Materials and methods}

The experiment was conducted at the Laboratory of Sugar and Alcohol Technology, College of Agricultural and Veterinary Sciences/UNESP - Jaboticabal, SP, Brazil.

The experimental design used was a $4 \times 2$ factorial arrangement with four replications. The main treatment included the extracted original sugarcane juice and three flocculating agents: synthetic polyelectrolyte, Moringa leaf extract, and the control. The secondary treatment consisted of the sugarcane varieties RB867515, the most cultivated variety in Brazil accounting for approximately 25\% of the cultivated land area, and RB92579, which predominates in 54\% of the land areas in the northeastern region of Brazil and is rich in compounds that increase color and amount of sugar. The two raw materials were manually harvested, without previous straw burning from sugarcane cultivation lands in the region of municipality of Jaboticabal in August (first variety) and September (second variety) 2011 (harvest season of 2011/2012).

After harvest, the stalks were subjected to the process of juice extraction using a laboratory scale cane crusher. The juice extracted was treated according to the CTC (Centro de Tecnologia Canavieira, 2005), which consisted of adding $300 \mathrm{mg} / \mathrm{L}$ of phosphorus (phosphoric acid), followed by $6^{\circ} \mathrm{Be}$ calcium hydroxide until reaching $\mathrm{pH} 7.0 \pm 0.1$ to obtain limed juice. It was then heated to boiling in order to accelerate the reaction between the calcium and phosphate and transferred to graduated cylinders that respectively contained the flocculating agents. After 20 minutes, the juice was filtered through a qualitative filter paper (Qualy, $18.5 \mathrm{~cm}$ diameter and $14 \mathrm{~mm}$ porosity).

The Moringa oleifera Lam. leaf extract was obtained from fresh leaves of the plant harvested in August 2011 in Jaboticabal. The extract was prepared according to the method described by Ghasi et al. (2000) and added to the juice at the concentration of $5 \mathrm{mg} / \mathrm{L}$ (dosage defined after preliminary testing).

The synthetic polyelectrolyte Flomex 9076 was used at the dose of $1.5 \mathrm{mg} / \mathrm{L}$ (dosage defined after preliminary testing).

The following analyses were carried out in both the original and clarified juices to evaluate the efficiency of the flocculating agent: brix content, total reducing sugars, soluble ash, color (Centro de Tecnologia Canavieira, 2005), total phenolic compounds, (Folin \& Ciocalteu, 1927) amino acids (Yemm \& Cocking, 1955), proteins (Bailey, 1967). Particle sedimentation rate (settling rate) and sludge volume (Centro de Tecnologia Canavieira, 2005) were also determined during the settling process.

In order to evaluate the effect on the microorganisms, the original and clarified juices were inoculated into three different specific culture media: WLN (yeast) (Stroppa et al., 2009), MRS (lactic acid bacteria) (Man et al., 1960), and PCA (total microorganisms) (Foods and Drugs Administration of United States of America, 1995), and the results were expressed as colony-forming units $(\mathrm{CFU} / \mathrm{mL})$.

After juice clarification, the clarified juice was concentrated until a brix of $60^{\circ}$ (syrup) using a simple-effect evaporator. The syrup was boiled in a pilot pan with controlled temperature of $61 \pm 2{ }^{\circ} \mathrm{C}$. The graining was performed by adding "seeds" (small crystals of uniform size in which sucrose is deposited). The sugar boiling process was kept in a supersaturated metastable zone by adding syrup $60^{\circ}$ Brix.

The massecuite, product with sugar crystals and liquid impurities (molasses), was centrifuged $(6300 \mathrm{~g})$ for 5 minutes to separate the crystals from molasses. Steam (pressure $1 \mathrm{kgf} / \mathrm{cm}^{2}$ ) was used to wash the sugar in the begging of centrifugation. Sugar was initially dried in a hot air drier, and then it was placed in an incubator at $35^{\circ} \mathrm{C}$ for 12 hours.

Sugar quality was determined by the analysis of Pol, $\mathrm{pH}$, moisture, color, phenolic compounds (Centro de Tecnologia Canavieira, 2005), security factor (Rein, 2012), quantity of mold and yeast (Beuchat et al., 2007), total coliforms (Hosokawa \& Kodaka, 2010), and Salmonella (Kodaka et al., 2005).

The results obtained were subjected to analysis of variance using the $\mathrm{F}$ test, and the means were compared using the Tukey's test (5\%) and the ASSISTAT 7.6 beta software (Campina Grande-PB). The results of protein, sedimentation rate, and sludge volume were subjected to square root transformation.

\section{Results and discussion}

\subsection{Clarified juice}

The first step was to evaluate the effects of the juice treatment with different flocculating agents on the sugars present in two sugarcane varieties. There was no change in the amount of sugars in the clarified juice when compared to the original juice since the process of juice clarification by simple defecation does not remove the sugars from the juice; it removes only insoluble substances and a small amount of soluble solids (Coca et al., 2008). It is worth mentioning that the two sugarcane varieties used had the same amount of soluble solids and total reducing sugars, both in the range of $22 \%$ and $19 \%$, respectively.

Next, the soluble ashes were quantified in both the original and clarified juices from the two sugarcane varieties investigated. The juice extracted from the variety RB867515 had double the ash content of the variety RB92579 (Figure 1). Therefore, under these conditions, the clarification of the juice extracted from the variety RB92579 did not result in the decrease or increase in the content of this compound. However, only the juice treated with Moringa leaf extract significantly reduced the ash content of the variety RB867515, whereas the other treatments increased it, compared to that of the original juice. The increase of this compound in the clarified juice from the variety RB867515 may be related to the calcium added during the clarification process, and only the leaf extract resulted in the high sludge volume facilitating their removal. It should be considered that the ash content of the juice indicates the amount of soluble ionic salts present in a sugar solution, such as calcium, potassium, phosphorus, and magnesium, among others (Foods and Drugs Administration of United States of America, 2014).

The protein content was quantified in both the original and clarified juices from the two sugarcane varieties using 
different flocculating agents. There was significant reduction in the protein in the different clarified juices compared to that of the original juice extracted from the two varieties of sugarcane investigated (Figure 2). The reduction in these biomolecules is essential for the production of high quality sugar since if it remains in the process, it can lead to increased viscosity of the syrup produced, besides reducing the rate of crystallization of sucrose. It is important to mention that the elimination of protein during the juice treatment results primarily from boiling since under these conditions protein coagulation and consequent precipitation take place (Albuquerque et al., 2011).

The soluble amino acid content was quantified in both the original and clarified juices from the two sugarcane varieties since amino acids are color precursors in the sugar produced due to their ability to react with reducing sugars and form colored complexes (Maillard Reaction) (Coca et al., 2008). The clarification process had different effects on the content of amino acids in the clarified juice for the two sugarcane varieties tested (Figure 3). There was an increase in these compounds in the

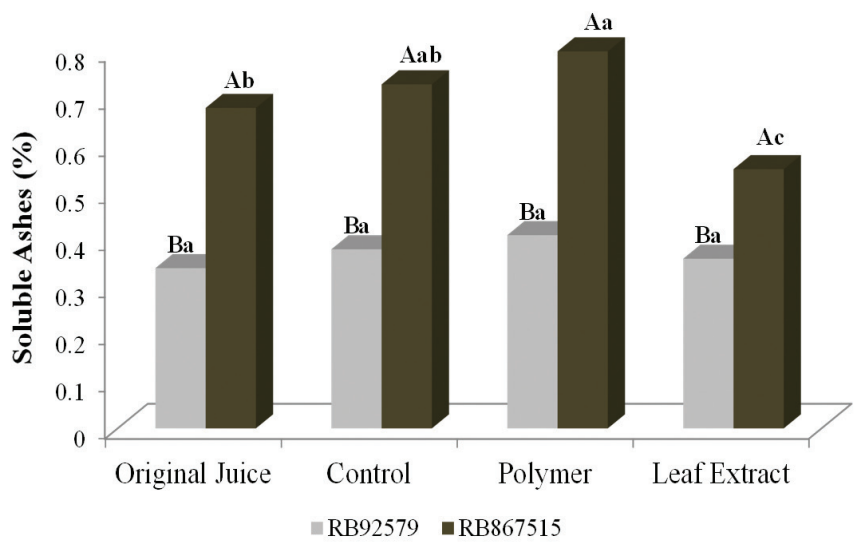

Figure 1. Interaction between ashes in the juice extracted from the two varieties of sugarcane treated with different flocculating agents (Jaboticabal, SP, harvest season of 2011/2012). Lowercase letters compare the main treatments (flocculating agents), and uppercase letters compare secondary treatments (varieties).

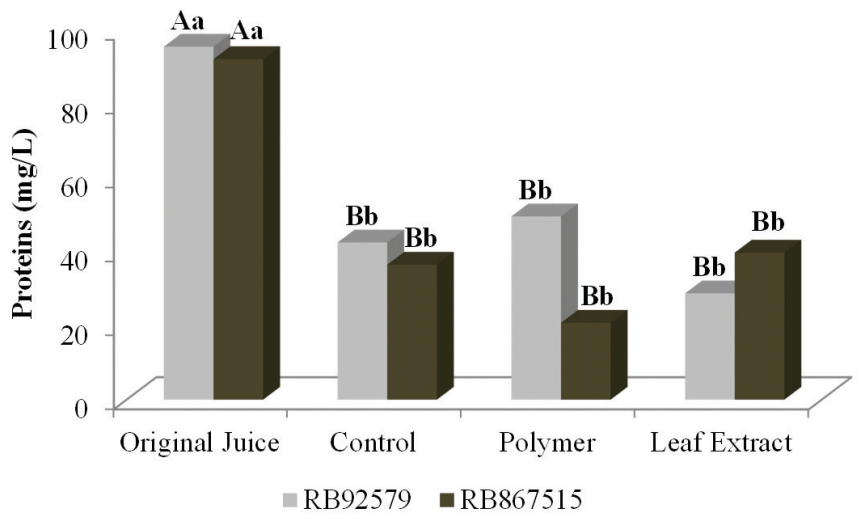

Figure 2. Interaction between proteins in the juice extracted from the two varieties of sugarcane treated with different flocculating agents (Jaboticabal, SP, harvest season of 2011/2012). Lowercase letters compare the main treatments (flocculating agents), and uppercase letters compare secondary treatments (varieties). variety RB92579, but there was no change in the concentration of amino acids in the variety RB867515 compared to that of the original juice. The amino acid content increase in the variety RB92579 may be associated with the hydrolysis of proteins during the heating process. It is worth mentioning that the use of different flocculating agents did not affect the amount of amino acids in the clarified juice.

The phenolic compounds were quantified in both the original and clarified juices using different flocculating agents. The conventional treatment (synthetic polyelectrolyte) did not reduce the amounts of these biomolecules during the clarification process, which is in agreement with Albuquerque (2011). However, the extract of Moringa leaves removed significant amount of these compounds compared to that in the original juice (Table 1). These are promising results since phenolic compounds can react with iron ions present in the juice resulting in a colored complex that increases the color of the sugar thus reducing the price in the market (Simioni et al., 2006). It is worth mentioning that the variety RB92579 had

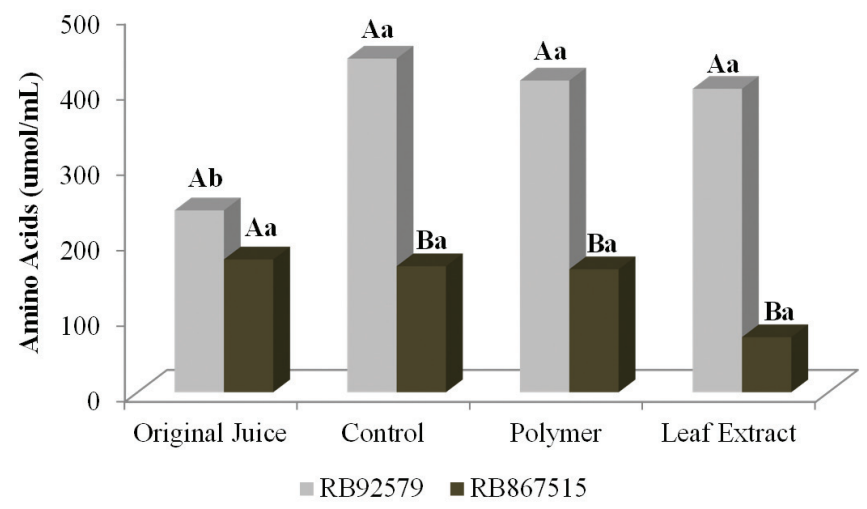

Figure 3. Interaction between amino acids in the juice extracted from the two varieties of sugarcane treated with different flocculating agents (Jaboticabal, SP, harvest season of 2011/2012). Lowercase letters compare the main treatments (flocculating agents), and uppercase letters compare the secondary treatments (varieties).

Table 1. Mean values of protein, total amino acids, phenolic compounds, color, and dextran of the original and clarified juices extracted from the varieties RB92579 and RB687515.

\begin{tabular}{cc}
\hline Treatment & Phenolic Compounds $(\mathrm{mg} / \mathrm{L})$ \\
\hline Original Juice & $580.15 \mathrm{AB}$ \\
Control & $479.03 \mathrm{C}$ \\
Polymer & $623.14 \mathrm{~A}$ \\
Leaf Extract & $513.72 \mathrm{BC}$ \\
F Test & $8.47^{\star *}$ \\
DMS & 86.84 \\
RB92579 & $630.58 \mathrm{~A}$ \\
RB867515 & $467.44 \mathrm{~B}$ \\
F Test & $53.68^{\star *}$ \\
DMS & 45.97 \\
C.V. & 11.47 \\
Inter. TxV & $1.38 \mathrm{~ns}$ \\
\hline
\end{tabular}

Values followed by the same letter are not significantly different according to the Tukey test at $5 \%$ probability; ns $=$ not significant; ${ }^{* *}=$ significant at $1 \%$. 
higher content of phenolic compounds than that of RB867515, in agreement with data available in the literature.

During the sugarcane juice clarification process, there is the removal of some compounds, such as chlorophyll and anthocyanins, which otherwise would enhance the color of sugar (Coca et al., 2008). Therefore, the color of the original and clarified juices was quantified in the two sugarcane varieties using different flocculating agents. The two varieties investigated showed different behavior when subjected to the clarification process. There was no change in the color of the clarified juice compared to that of the original juice from the variety RB867515; on the other hand, there was significant reduction in the color of the clarified juice from the variety RB92579, and the Moringa leaf extract produced the best results (Figure 4). Since the variety

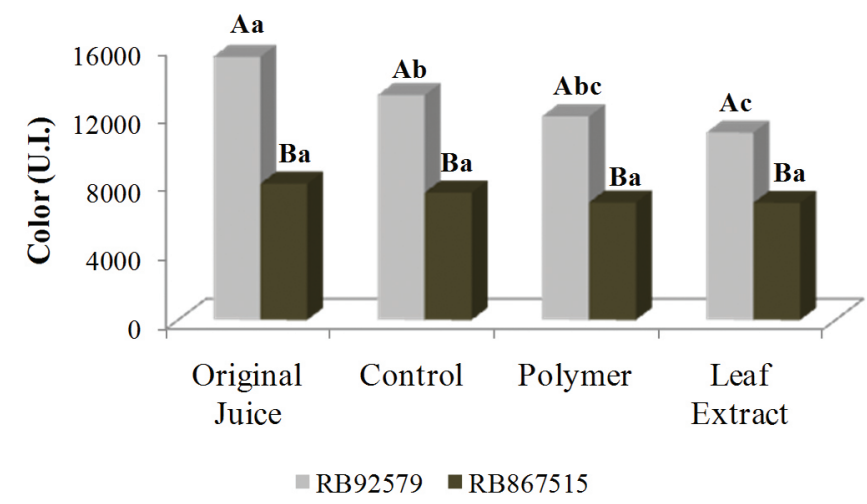

Figure 4. Interaction between color in the juice extracted from the two varieties of varieties of sugarcane treated with different flocculating agents (Jaboticabal, SP, harvest season of 2011/2012). Lowercase letters compare the main treatments (flocculating agents), and uppercase letters compare the secondary treatments (varieties).

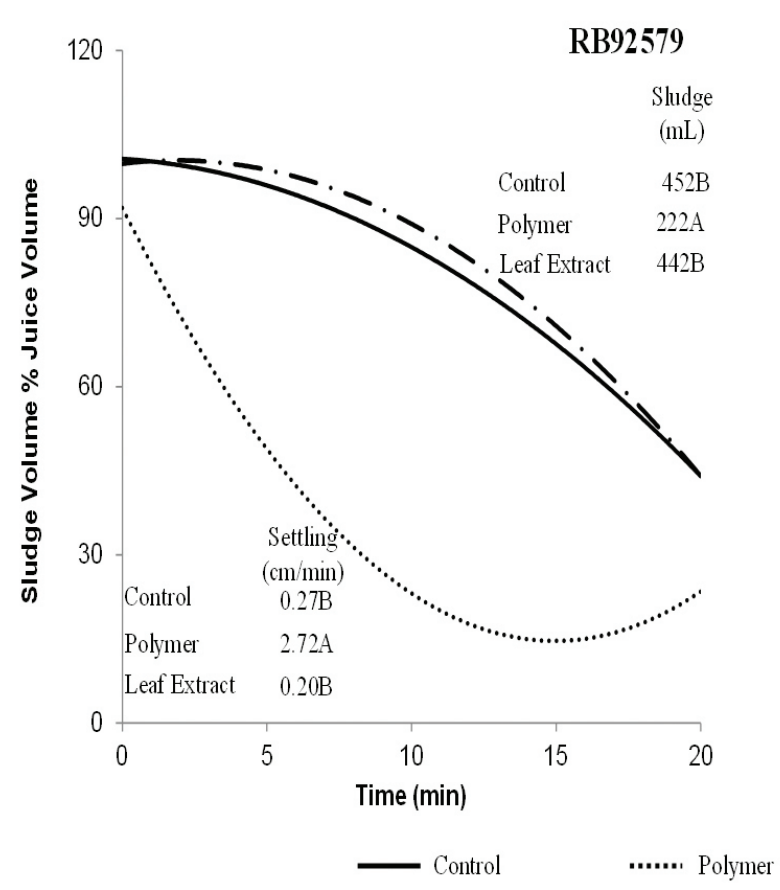

RB92579 has high amounts of compounds, such as phenolic compounds, which increase the color of the clarified juice, the result obtained with the leaf extract is of great importance for the sugar industry since the common clarification process of this sugarcane variety, which uses synthetic flocculating agents, does not remove enough color to produce high quality sugar.

The presence of yeast, bacteria, and microorganisms was detected in both the original and clarified juices from the two sugarcane varieties. The clarification process reduced the amount of microorganisms in the clarified juice to concentrations below $10^{2} \mathrm{CFU} / \mathrm{mL}$. RB92579 had smaller amount of yeast compared to that of RB867515, which is probably associated with its higher amount of phenolic compounds, inhibitors of the yeast metabolism (Ravaneli et al., 2011).

In order to characterize the operational aspects of the clarification process using Moringa leaf extract, the settling rate and the sludge volume were evaluated. The conventional treatment (Flomex 9076) resulted in a higher settling rate of the flakes and a smaller amount of sludge compared to those obtained with the extract of Moringa leaves for both sugarcane varieties. However, as can be seen in Figure 5, the Moringa leaf extract promoted high rate clarification results after 10 minuterest. Since this experiment lasted 20 minutes, further studies with one hour experiment are recommended for a more accurate settling rate and sludge volume evaluation. The volume of the flake sediment was 33\% higher in the variety RB867515 than in RB92579; a fact that may be associated with the high amounts of ash in the former variety since when some compounds, such as phosphorous, are in excess in the juice (above $300 \mathrm{mg} / \mathrm{L}$ ), they can lead to sludge with higher volume and low density (Doherty, 2009).

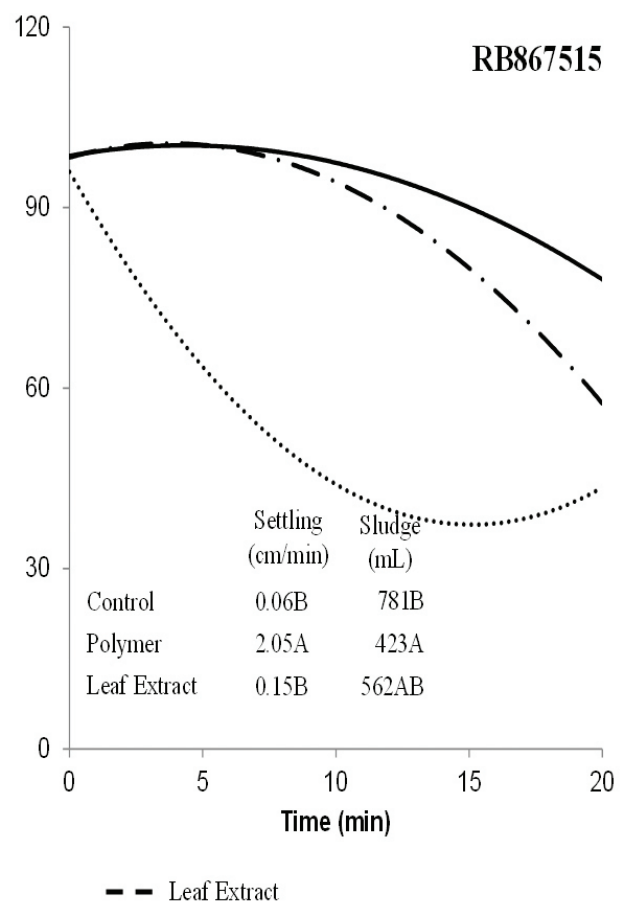

Figure 5. Sludge Volume \% juice volume as a function of time during the treatment of the sugarcane juice using the varieties RB92579 and RB867515. (Jaboticabal, SP, harvest season of 2011/2012). 


\subsection{Sugar}

After the clarification process, the juice was concentrated using a simple effect evaporator until a brix of $60^{\circ}$ (syrup). The syrup was cooked in a laboratory pan under controlled temperature and vacuum and kept in a supersaturated metastable zone using seeds to growth the crystals. Sugar was recovered by centrifugation $(6300 \mathrm{~g})$, oven-dried and analyzed for Pol, color, total phenolic compounds, $\mathrm{pH}$, moisture, security factor, salmonella, mold and yeasts, and total coliforms.

It was observed that the different flocculating agents did not affect the saccharose content of sugars crystals ( $\mathrm{Pol})$. The values were close to $97 \%$. The flocculating agents behavior was also analyzed in terms of total phenolic compounds $(260 \mathrm{mg} / \mathrm{kg}$ ) and $\mathrm{pH}$ (6.2), and the different flocculating agents did not affect the concentration of these compounds in the sugar produced.

Analyzing the color of the products, it was verified that the treatment with Moringa Leaf extract resulted in lighter colored sugar if compared to the results of the conventional treatment (Table 2). This fact is very important for sugar industries because this parameter is one of the items required for soft drinks industries, for example, sugar color can darken clear sodas shortening their shelf life (Oliveira et al., 2007). Therefore, the lighter the sugar, the better its price in the market.

No differences were found comparing the color of sugar produced from different sugarcane varieties (Table 2). The variety RB92579 has higher level of compounds that promote color in crystals, such as phenols; however, in order to produce color, it is necessary oxygen and iron ions (element present in industrial equipment), which probably were not present in the processing since the syrup was cooked in a glass equipment, and thus such reaction did not occur.

Since water is indispensable for microorganism growth, the presence of moisture in sugars crystals may promote this microbiological deterioration, resulting in reduced time of storage of this product. Accordingly, it was observed the beneficial effect of moringa leaf extract on sugar production

Table 2. Average values of moisture and color of sugars obtained from juice clarification using different flocculating agents for two sugarcane varieties.

\begin{tabular}{ccc}
\hline Treatment & Color (U.I.) & Moisture (\%) \\
\hline Control & $1304 \mathrm{~A}$ & $0.34 \mathrm{~A}$ \\
Polymer & $1243 \mathrm{AB}$ & $0.30 \mathrm{~A}$ \\
Leaf Extract & $1016 \mathrm{~B}$ & $0.25 \mathrm{~B}$ \\
F Test & $4.62^{\star}$ & $24.14^{* *}$ \\
DMS & 254.85 & 0.04 \\
RB92579 & $1195 \mathrm{~A}$ & $0.26 \mathrm{~B}$ \\
RB867515 & $1180 \mathrm{~A}$ & $0.33 \mathrm{~A}$ \\
F Test & $0.03 \mathrm{~ns}$ & $14.76^{\star *}$ \\
DMS & 171.19 & 0.02 \\
C.V. & 16.81 & 11.52 \\
Inter. TxV & $3.53 \mathrm{~ns}$ & $2.06 \mathrm{~ns}$ \\
\hline
\end{tabular}

Values followed by the same letter are not significantly different according to the Tukey at $5 \%$ probability; $\mathrm{ns}=$ not significant; ${ }^{*}=$ significant at $5 \%$; ${ }^{*}=$ significant at $1 \%$. since it reduced $17 \%$ of this parameter compared to the effect produced by the conventional treatment (polymer) (Table 2).

In order to determine how long sugar can be stored, the security factor (moisture/Pol x 100) was calculated. All treatments showed the same security factor value $(0.10)$, which is a good result since the maximum value recommended for storage of this product is 0.25 (Rein, 2012). Accordingly, the presence of microorganisms (mold, yeast, total coliforms and salmonella) was not detected in all treatments. These results are better than those found by Wojtczak et al. (2005), who detected yeasts and bacteria in commercials sugar in Europe. Those microorganisms are harmful to humans and must be eliminated. However, it should be noted that these microorganisms are carried from the field along with the raw material or may appear in the final operation of sugar product, such as low quality centrifugal water, human manipulation, sugar powder etc (Delgado \& Cesar, 1977).

\section{Conclusion}

The use of Moringa oleifera Lam. leaf extracts to assist impurity sedimentation in the treatment of sugarcane juice resulted in a better quality clarified juice and sugar compared to that obtained with the conventional treatment using synthetic polyelectrolyte.

Each variety tested had different behavior when subjected to simple defecation, the standard clarification process.

\section{Acknowledgments}

The authors a gratefully acknowledge CAPES (Brazilian research supporting foundation) for granting the research scholarship.

\section{References}

Albuquerque, F. M. (2011). Processo de Fabricação de Açúcar. (3. ed.). Recife: UFPE.

Bailey, I. L. (1967). Techniques in protein chemistry. (2nd ed.). Amsterdam: Elservier.

Beltrán-Heredia, J. \& Sánchez-Martin, J. (2009). Removal of sodium lauryl sulphate by coagulation/flocculation with Moringa oleifera seed extract. Journal of Hazardous Materials, 164(2-3), 713-719. PMid:18824298. http://dx.doi.org/10.1016/j.jhazmat.2008.08.053

Beuchat, L. R., Mann, D. A. \& Gurtler, J. B. (2007) Comparison of Dry Sheet Media and Conventional Agar Media Methods for enumerating yeasts and molds in food. Journal of Food Protection, 70, 2661-2667. PMid:18044453.

Centro de Tecnologia Canavieira - CTC (2005). Manual de métodos de análises para açúcar. Piracicaba: CTC.

Coca, M., Garcia, M. T., Mato, S., Catóns, A. \& González, G. (2008). Evolution of colorants in sugarbeet juices during decolorization using styrenic resins. Journal of Food Engineering, 89(3), 429-434. http://dx.doi.org/10.1016/j.jfoodeng.2008.05.025

Companhia Nacional de Abastecimento - CONAB. (2013). Acompanhamento da safra brasileira de cana-de-açúcar - $3 o$ levantamento safra 2013/2014. Retrieved from http://conab.gov.br/ OlalaCMS/uploads/arquivos/13_12_20_10_56_08_boletim_cana_ portugues_-_dez_2013_3o_lev_-_original.pdf. 
Delgado, A. A. \& Cesar, M. A. A. (1977). Elementos de tecnologia e engenharia do açúcar de cana. (2 Vol.) Sertãozinho: Zanini.

Doherty, W. O. S. (2009). Some aspects of calcium phosphate chemistry in sugarcane clarification. International Sugar Journal, 111(1327), 448-455.

Doherty, W. O. S. (2011) Improved Sugar Cane Juice Clarification by Understanding Calcium Oxide-Phosphate-Sucrose Systems. Journal of Agricultural and Food Chemistry, 59(5), 1829-1836. PMid:21322558. http://dx.doi.org/10.1021/jf1043212

Folin, O. \& Ciocalteu, V. (1927). On tyrosine and tryptophane determinations in proteins. The Journal of Biological Chemistry, 73(2), 627-650.

Foods and Drugs Administration of United States of America - FDA (2014). Government Printing Office. Retrieved from $<$ http://www. gpo.gov/fdsys/pkg/CFR-2012-title21-vol3/pdf/CFR-2012-title21vol3-sec173-10.pdf>

Foods and Drugs Administration of United States of America - FDA. (1995). Bacteriological Anal - Manual. (8th ed.). Maryland: AOAC International.

Ghasi, S., Nwobodo, E. \& Ofili, J. O. (2000). Hypocholesterolemic effects of crude extract of leaf of Moringa oleifera Lam in high-fat diet fed wistar rats. Journal of Ethnopharmacology, 61(1), 21-25. http://dx.doi.org/10.1016/S0378-8741(99)00106-3

Hosokawa, S. \& Kodaka, H. (2010). Efficacy of Compact Dry EC for coliform detection in seafood. International Journal of Food Microbiology, 27(2), 80-85.

Jank, M. S. (2011). Perspectivas para os mercados de açúcar e etanol. Retrieved from http://www.bmfbovespa.com.br/pt-br/download/ Marcos_Jank-Painel4.pdf.

Kodaka, H., Mizuochi, S., Teramura, H. \& Nirazuka, T. (2005). Comparison of the Compact Dry TC Method with the Standard Pour Plate Method (AOAC Official Method 966.23) for Determining Aerobic Colony Counts in Food Samples: Performance-Tested MethodSM. Journal of AOAC International, 88(6), 1702-1713. PMid:16526454.

Man, J. C., Rogosa, M. \& Sharpe, M. E. (1960). A medium for the cultivation of Lactobacillus. Journal of Applied Bacteriology, 23(1), 130-135. http://dx.doi.org/10.1111/j.1365-2672.1960.tb00188.x
Ndabigengesere, A. \& Narasiah, K. S. (1998). Quality of water treated by coagulation using Moringa oleifera seeds. Water Research, 32(3), 781-791. http://dx.doi.org/10.1016/S0043-1354(97)00295-9

Oliveira, D. T., Esquiaveto, M. M. M. \& Silva Junior, J. F. (2007). Impacto dos itens da especificação do açúcar na indústria alimentícia. Food Science \& Technology, 27(supl.), 99-102.

Pritchard, M., Craven, T., Mkandawire, T., Edmondson, A. S. \& O’Neill, J. G. (2010). A comparison between Moringa oleifera and chemical coagulants in the purification of drinking water - An alternative sustainable solution for developing countries. Physics and Chemistry of the Earth, 35(13-14), 798-805. http://dx.doi.org/10.1016/j. pce.2010.07.014

Ravaneli, G. C., Garcia, D. B., Madaleno, L. L., Mutton, M. A., Stupiello, J. P. \& Mutton, M. J. R. (2011). Spittlebug impacts on sugarcane quality and ethanol production. Pesquisa Agropecuária Brasileira, 46(2), 120-129. http://dx.doi.org/10.1590/S0100204X2011000200002

Rein, P. (2012). Cane Sugar Engineering (2nd ed.). Berlin: Bartens.

Simioni, K. R., Silva, L. F. L. F., Barbosa, V., Re, F. E., Bernadino, C. P., Lopes, M. L. \& Amorim, H. V. (2006). Efeito da variedade e época de colheita no teor de fenóis totais em cana-de-açúcar. Stab Açúcar, Álcool e Subprodutos, 24(3), 36-39.

Stroppa, T., Alves, J. G. L. F., Figueiredo, A. L. F. \& Castro, C. C. (2009). Parâmetros cinéticos de linhagens de levedura isoladas de alambiques mineiros. Ciência e Agrotecnologia, 33, 1978-1983. http://dx.doi.org/10.1590/S1413-70542009000700048

Vaz, L. G. L., Klen, M. R. F., Veiti, M. T., Silva, E. A., Barbiero, T. A. \& Bergamasco, R. (2010). Avaliação da eficiência de diferentes agentes coagulantes na remoção de cor e turbidez em efluente de galvanoplastia. Ecletica Quimica, 35(4), 45-54. http://dx.doi. org/10.1590/S0100-46702010000400006

Wojtczak, M., Biernasiak, J. \& Papiewska, A. (2005). Evaluation of microbiological purity of raw and refined white cane sugar. Food Control, 25(1), 136-139. http://dx.doi.org/10.1016/j. foodcont.2011.10.031

Yemm, E. W. \& Cocking, E. C. (1955). The determination of amino acids with ninhydrin. Analyst, 80, 209-213. http://dx.doi.org/10.1039/ an9558000209 